\title{
Status and conservation of Yellow-headed Parrot Amazona oratrix "guatemalensis" on the Atlantic coast of Guatemala
}

\author{
KNUT EISERMANN
}

\begin{abstract}
Summary
In 2001 the abundance of Yellow-headed Parrot Amazona oratrix "guatemalensis" at a roost site in Punta de Manabique, Guatemala was found to be 70 individuals. A comparison with a roost census in 1994 suggested a population decline. The largest threat to this form of Yellow-headed Parrot is nest-robbing for the pet trade. The rate of decline and the limited number of individuals living in the wild suggest the population is facing extinction. The core zone of reproduction is located in a palm savanna. Information on feather patterns of the head of this form of A. oratrix is provided.
\end{abstract}

\section{Introduction}

Yellow-headed Parrot Amazona oratrix is endemic to northern Central America, with several subspecies occurring in Mexico, Belize, Guatemala and Honduras (Juniper and Parr 1998). While the taxonomic status of these subspecies is not yet clear (Howell and Webb 1995), Lousada and Howell (1996) describe a form named Amazona oratrix "guatemalensis" found on the Atlantic coast of Guatemala, and emphasize the special threat to this population. The status of this population and the threats it faces were described in Collar et al. (1992). A. oratrix is considered globally Endangered by IUCN (Hilton-Taylor 2000) and BirdLife International (2000).

In 2001 a basic study was undertaken on the local avifauna of the Punta de Manabique protected area (hereafter Manabique) in Izabal, Guatemala (Eisermann 2001). I attempted to evaluate the status of Yellow-headed Parrot, using roost counts, and compared the results with previous estimates.

\section{Study area and methods}

The peninsula of Punta de Manabique is a marine and terrestrial protected area on the Atlantic coast of Guatemala ( $15^{\circ} 50^{\prime} \mathrm{N} 88^{\circ} 30^{\prime} \mathrm{W}$ ) (Figure 1). The terrestrial area covers $670 \mathrm{~km}^{2}$ and is characterized by palm swamp forests, coastal brush, mangrove, and a mosaic of forest fragments and agricultural land. About 2,000 people live inside the limits of the protected area (INE 1994) and practise fishing, charcoal-making, cattle farming and other agricultural activities for subsistence. More than 320 bird species are known to occur in Manabique (Eisermann 2001).

In order to estimate the population size of Yellow-headed Parrot, I conducted 


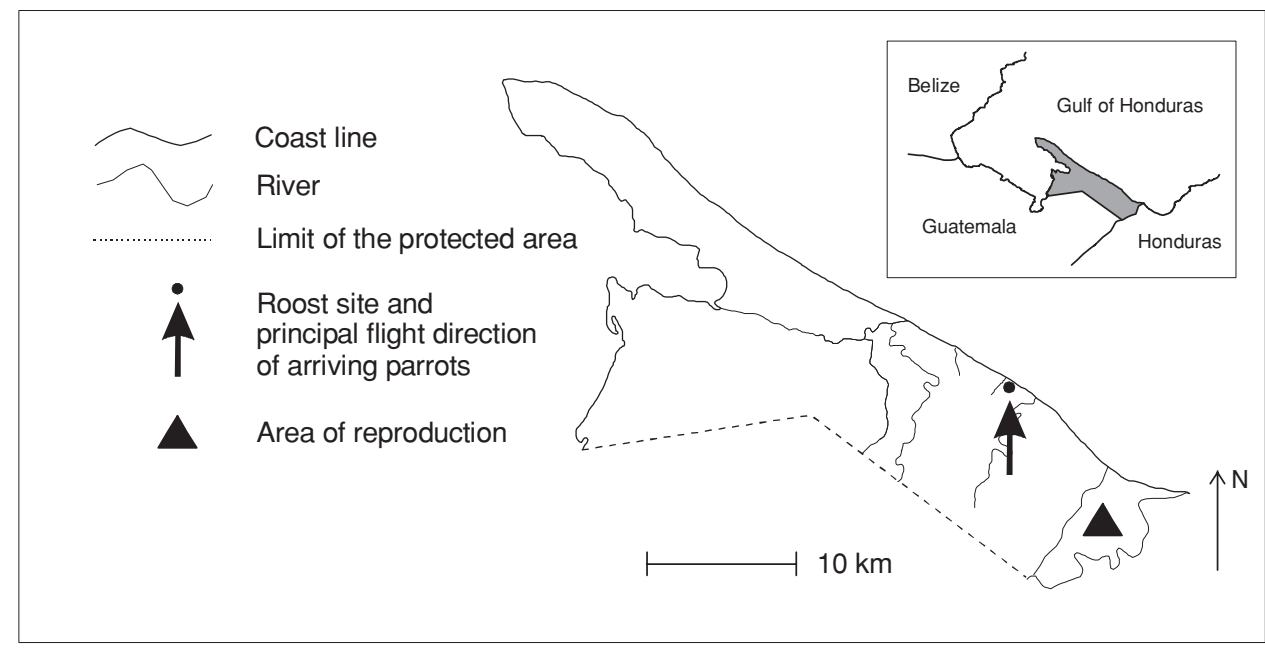

Figure 1. The Punta de Manabique protected area surveyed for Yellow-headed Parrot Amazona oratrix.

counts on a traditional roosting site. According to interviews with local people it was the only known night roost. Censuses with two observers took place before and after the breeding season (8 January, 6 May, 14 June 2001). As they arrived at the roost the parrots were readily observed since the roost was in an isolated stand of tall mangroves surrounded by the sea and swamp shrub. Calling parrots were clearly distinguishable from other large Amazon parrots Amazona spp. even at dusk. Wind strength was classified according to the Beaufort Wind Scale.

\section{Results}

\section{Habitat}

I documented Yellow-headed Parrots nesting in palm savanna and mangrove forest. During the reproductive period in April, A. oratrix were most abundant in an open palm savanna dominated by Roystonea oleracea. The understorey consisted of various species of grass, some up to $2 \mathrm{~m}$ tall. The area was used for low intensity cattle grazing. This palm savanna is usually flooded during the rainy season (June-January, L. Salgero, pers. comm.).

Most nest holes were found in snags of Roystonea, but were also found in trunks of other trees with suitable cavities (e.g. Salix spp.). Three nest cavities were located along the coastline of Manabique in old red mangroves (Rhizophora mangle), some as high as $20 \mathrm{~m}$ tall. In April, when juveniles were growing within the nest holes, I made an observation of feeding adults. The majority of nest holes previously observed were destroyed by poachers. Trunks were either chopped down, their entrance considerably widened, or a hole made at nest height, when the nest cavity bottom was considerably below the entrance.

A traditional roosting site was situated in a stand of tall $(20 \mathrm{~m})$, mostly dead mangrove stands on the beach. Parrots were observed using trees $10-50 \mathrm{~m}$ from 
the waterline, with the wind strength 7 . It is unknown if parrots use the same trees in nights with stronger winds. Local people report the roost has existed for more than 10 years (C. Palencia, pers. comm.). The distance between the core area of reproduction and the roost site was approximately $13 \mathrm{~km}$.

\section{Abundance and status}

In order to estimate the abundance of parrots, repeated censuses were conducted at a traditional roosting site. Parrots arrived soon after sunset within 45 and $80 \mathrm{~min}$, in pairs or groups of three individuals, congregating in the upper canopy of 7-10 mangrove trees. Between January and June, five Brown Pelicans Pelecanus occidentalis and a pair of Red-lored Parrot Amazona autumnalis roosted in the same trees. During January 2001 and before the breeding season, 6o individuals of Yellow-headed Parrot were counted, and in May and June, after fledging of juveniles, 68 individuals were recorded, suggesting low reproductive success.

I recorded the distribution pattern of yellow head feathers of six parrots (Figure 2) to further document exterior features of the Manabique population as provided by Lousada and Howell (1996) since the taxonomic status of the intermediate form A. oratrix "guatemalensis" is still unclear. Three wild individuals (a, b, c in Figure 2) were observed clearly on 8 May 2001 at the roosting site after sunrise. Photographs were taken of these and also of three captured individuals in huts of local Guatemalans. Table 1 provides a characterization of the unfeathered parts of the three captured individuals.

\section{Discussion}

Semideciduous and deciduous forests, moist forest, gallery forests, pine savannas, mangroves and coastal shrub have been reported as habitat of $A$. oratrix (Collar et al. 1992, Howell and Webb 1995, Lousada and Howell 1996, England 2000). The use of Roystonea palm savanna has not been described previously and seems to be a unique trait of the Manabique population. However, the structure of this vegetation is similar to pine savanna.

Lousada and Howell (1996) counted about 100 individuals in Manabique at the traditional and only known roosting site in 1994. The difference in counts between 1994 and 2001 could indicate a population decline of some 30\%. These results underlie the dramatic decline of the species in most of its range (Snyder et al. 2000). Due to habitat destruction and natural barriers, the Manabique population of A. oratrix "guatemalensis" is isolated from other populations (Lousada and Howell 1996). It may be therefore, that Yellow-headed Parrot is seriously threatened in Manabique.

The primary threats to Yellow-headed Parrot throughout its range are nestrobbing for the pet trade and loss of habitat (Snyder et al. 2000). The Manabique population suffers from this illegal trade, which is organized from Honduras, but only three parrots were seen in huts of local Guatemalans during 10 months in the field. Nest-robbers cross the border armed and carrying machetes, axes and ropes (L. Salgero pers. comm.). Nest cavities and trees are almost always destroyed when poaching juveniles or eggs. Therefore, the population faces a 

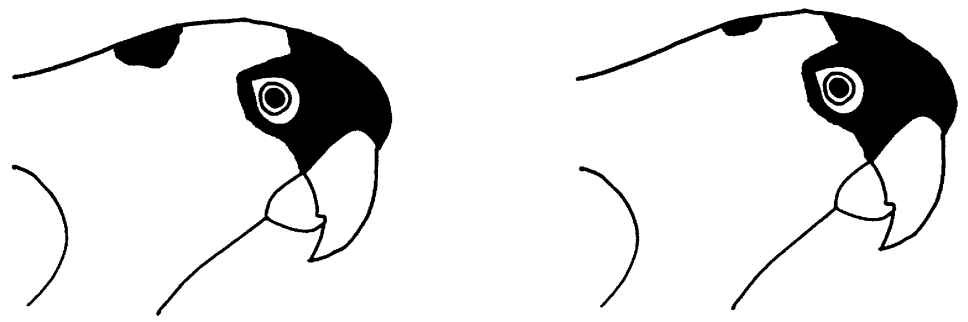

a
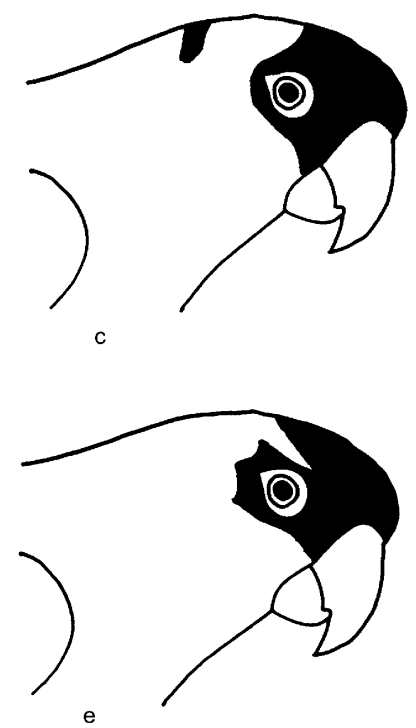

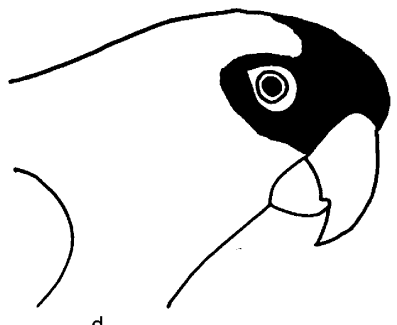

d

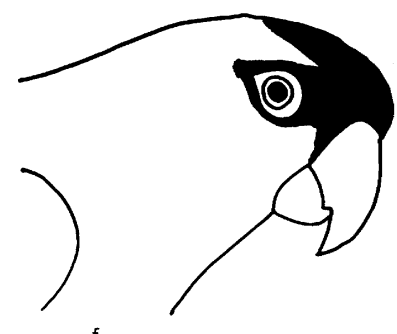

Figure 2. Distribution pattern of yellow head feathers (drawn in black) among different individuals of Amazona oratrix in Punta de Manabique according to photos by K. Eisermann. (a, b) wild-living couple, (c) wild-living individual, (d) captive individual at the age of 1 year, (e) captive individual at the age of 3 years, (f) captive individual at the age of 4 years.

Table 1. Exterior features (referring to Lousada and Howell 1996) of three captive individuals of Amazona oratrix.

\begin{tabular}{llll}
\hline & 4-year-old bird & 3-year-old bird & 1-year-old bird \\
\hline Claws & Dark & Pale & Dark \\
Mandibles & Very pale & Very pale & Pale \\
Cere/bristle & Pale/pale & Pale/pale & Grey/pale \\
Orbital ring/eyelid edge & Pale/dark & Pale/dark & Pale/dark \\
\hline
\end{tabular}

loss of productivity, not only due to the loss of individuals, but also due to the declining number of potential nesting sites. An additional threat to A. oratrix is hunting, evidenced by the discovery of parrot wings beside a fireplace in a local fishing camp near the roosting site. Available suitable habitat is further 
threatened by intensive cattle grazing, which is practised even within the protected area.

A. oratrix "guatemalensis" is considered an intermediate form between the recognized subspecies A. oratrix belizensis and A. oratrix hondurensis (Lousada and Howell 1996, 1997). My characterization of clearly observed individuals matches closely the description in Lousada and Howell (1996) and further documents the exterior features of this small population.

Punta de Manabique is a designated wildlife refuge. In order to preserve the Manabique population of Yellow-headed Parrot, planning and conservation administered by FUNDARY (Fundación Mario Dary), should be focused in the short term on preventing nest-robbing.

\section{Acknowledgements}

I thank FUNDARY for the technical support and Cesar Paz, Edy Troches and Lucio Salgero for the field assistance. I appreciate critical and helpful comments on the manuscript made by James D. Gilardi, Seb Buckton, Dylan Stearns, Jessica Eberhard and Francisco Villela, who also improved the English usage provided through the Association of Field Ornithologists' programme of editorial assistance. Results presented here are part of a study supported by the National Fish and Wildlife Foundation and USAID.

\section{References}

Bird Life International (2000) Threatened birds of the world. Barcelona and Cambridge, U.K.: Lynx Ediciones and Bird Life International.

Collar, N. J., Gonzaga, L. P., Krabbe, N., Madroño Nieto, A., Naranjo, L. G., Parker, T. A. III and Wege, D. C. (1992) Threatened birds of the Americas: the ICBP/IUCN Red Data Book. Washington, D.C. and Cambridge, U.K.: Smithsonian Institution Press, and International Council for Bird Preservation.

Eisermann, K. (2001) Caracterización de la avifauna del Ńrea de Protección Especial Punta de Manabique, Izabal, Guatemala. Unpub. Report FUNDARY, Guatemala.

England, M. (2000) The landbird monitoring programme at Lamanai, Belize: a preliminary assessment. Cotinga 13: 32-43.

Hilton-Taylor, C. (2000) 2000 IUCN Red List of Threatened Species. Gland, Switzerland and Cambridge, U.K.: IUCN.

Howell, S. N. G. and Webb, S. (1995) A guide to the birds of Mexico and northern Central America. New York: Oxford University Press.

INE (1994) Censo de población, municipio Puerto Barrios. Guatemala: Instituto Nacional de Estadística.

Juniper, T. and Parr, M. (1998) Parrots: a guide to parrots of the world. New Haven, CT: Yale University Press.

Lousada, S. A. and Howell, S. N. G. (1996) Distribution, variation, and conservation of Yellow-headed Parrots in northern Central America. Cotinga 5: 46-53.

Lousada, A. S. and Howell, S. N. G. (1997) Amazona oratrix hondurensis: a new subspecies of parrot from the Sula valley of northern Honduras. Bull. Brit. Orni. Club 117: 205209 .

Snyder, N., McGowan, P., Gilardi, J. and Grajal, A. (2000) Parrots: status survey and conservation action plan. Gland, Switzerland and Cambridge, U.K.: IUCN. 
KNUT EISERMANN

Fundación Mario Dary (FUNDARY), 5a avenida 9-62, 3er Nivel Apto. 2, Zona 1, Guatemala Ciudad, Guatemala. Present address: P.O. Box 098 Periférico, Guatemala Ciudad, Guatemala.

Received 18 May 2002; revision accepted 4 June 2003 